\title{
ANALISIS FAKTOR YANG MEMPENGARUHI TINGKAT KEPATUHAN MASYARAKAT TERHADAP PROTOKOL KESEHATAN COVID-19
}

\section{Analysis of Factors Affecting the Level of Community Obedience of COVID- 19 Health Protocols}

\author{
Fitria Halimatuzzahro, ${ }^{1 *}$, Fariha Naharul Himma ${ }^{2}$, Regita Sania Ardhia Buamona ${ }^{3}$ \\ 1,2,3 Statistika, Fakultas Sains dan Teknologi, Universitas Airlangga \\ Jln. Dr. Ir. H. Soekarno, Mulyorejo, Surabaya, 60115, Indonesia
}

Corresponding author e-mail: 1*fitria.halimatuzzahro-2019@fst.unair.ac.id

\begin{abstract}
Abstrak
COVID-19 (Coronavirus Disease-2019) merupakan penyakit menular yang diakibatkan oleh jenis coronavirus yang baru ditemukan. Saat ini, COVID-19 telah ditetapkan sebagai pandemi di banyak negara, termasuk Indonesia. Hal tersebut menjadi alasan bagi pemerintah Indonesia untuk mewajibkan penerapan protokol kesehatan dalam penanganan COVID-19 ini. Meski begitu, tidak sedikit masyarakat yang abai. Berdasarkan hal tersebut, penelitian ini dilakukan untuk mengetahui faktor yang memengaruhi tingkat kepatuhan masyarakat terhadap protokol kesehatan. Metode yang diterapkan pada penelitian ini adalah analisis faktor dengan melibatkan delapan variabel. Berdasarkan hasil analisis, didapatkan dua faktor yang terbentuk yang diberi nama faktor persepsi tentang COVID-19 dan faktor persepsi tentang protokol kesehatan. Faktor persepsi tentang COVID-19 dibentuk oleh empat variabel, yaitu variabel pengetahuan $\left(X_{1}\right)$, kepercayaan terhadap pemerintah $\left(X_{2}\right)$, perceived susceptibility $\left(X_{3}\right)$, dan perceived severity $\left(X_{4}\right)$. Sementara itu, faktor persepsi tentang protokol kesehatan dibentuk oleh 4 variabel, yaitu variabel perceived benefit $\left(X_{5}\right)$, perceived barrier $\left(X_{6}\right)$, cues to action $\left(X_{7}\right)$, dan kejelasan informasi $\left(X_{8}\right)$.
\end{abstract}

Kata Kunci : Analisis Faktor, Kepatuhan, Protokol Kesehatan, COVID-19

\begin{abstract}
COVID-19 (Coronavirus Disease-2019) is an infectious disease caused by a new variant of coronavirus. Currently, COVID19 is declared as a pandemic in many countries in the world, including Indonesia. Hence, Indonesian government has declared an emergency status of COVID-19 in 2020. Based on that declaration, there is a mandatory implementation of health protocols to overcome the pandemic. Even so, there are some people who ignores it. Based on that situation, this study aims to determine the factors affecting the level of community obedience of health protocols. To do this study, data was analyzed using factor analysis by involving eight variables. The result shows that there is two factors, named factor of perception about COVID-19 and factor of perception about health protocols. Factor of perception about COVID-19 involves four variables, such as knowledge variable $\left(X_{1}\right)$, trust in government $\left(X_{2}\right)$, perceived susceptibility $\left(X_{3}\right)$, and perceived severity $\left(X_{4}\right)$. Meanwhile, factor of perception about health protocols also involves four variables, such as perceived benefit $\left(X_{5}\right)$, perceived barrier $\left(X_{6}\right)$, cues to action $\left(X_{7}\right)$, and clear information $\left(X_{8}\right)$.
\end{abstract}

Keywords: Factor Analysis, Obedience, Health Protocols, COVID-19

Article info:

Submitted: 12 May $2021 \quad$ Accepted: $17^{\text {th }}$ October 2021

How to cite this article:

F. Halimatuzzahro', F. N. Himma, and R. S. A. Buamona, "ANALISIS FAKTOR YANG MEMPENGARUHI TINGKAT KEPATUHAN MASYARAKAT TERHADAP PROTOKOL KESEHATAN COVID-19”, BAREKENG: J. Il. Mat. \& Ter., vol. 15, no. 4, pp. 629-638, Dec. 2021. 


\section{PENDAHULUAN}

COVID-19 merupakan nama pemberian Wolrd Health Organization (WHO) bagi virus novel corona 2019. Virus ini pertama kali muncul di Kota Wuhan, Cina, pada akhir tahun 2019. Virus ini menular dengan cepat di berbagai negara, termasuk Indonesia [1]. Di Indonesia, pemerintah telah menetapkan COVID-19 sebagai penyakit yang menimbulkan darurat kesehatan masyarakat sesuai dalam Keputusan Presiden Nomor 11 Tahun 2020 [2]. Ketetapan tersebut mewajibkan upaya penanggulangan pada masa tanggap darurat COVID-19 dilakukan sesuai peraturan perundang-undangan.

Persebaran virus COVID-19 tergolong sangat cepat antar manusia. Hal ini dapat diketahui dari data persebaran kasus positif dari virus ini yang berkembang dengan signifikan di masyarakat sehingga perlu dilakukan sebuah upaya untuk memutus penyebaran dari virus ini. Penanganan dan pencegahan kasus pandemi ini sudah dilakukan dengan berbagai cara, baik secara global maupun nasional atau wilayah. Empat strategi yang selama ini sudah dijalankan untuk penanganan COVID-19, yaitu gerakan memakai masker, tracing atau penelusuran kontak dari kasus positif dari hasil rapid test, edukasi dan persiapan dalam melakukan isolasi mandiri pada masyarakat yang menunjukan hasil positif pada rapid test atau negatif dengan gejala, serta strategi isolasi rumah sakit yang dilakukan jika isolasi mandiri tidak memungkinkan untuk dilakukan karena terdapat tanda klinis yang membutuhkan layanan di rumah sakit [3].

Strategi yang dijalankan tersebut belum menunjukkan dampak positif dalam menekan kasus yang ada sehingga dengan mengevaluasi sifat dari virus ini, yaitu dapat menular lewat udara dan memiliki masa inkubasi 14 hari, pemerintah kembali mengeluarkan kebijakan melalui Kemendagri. Kebijakan tersebut diantaranya pemberlakuan isolasi diri yang mewajibkan semua masyarakat untuk selalu berada di dalam rumah, pelaksanaan karantina negara dan wilayah, serta Pembatasan Sosial Berskala Besar atau PSBB bagi wilayah yang statusnya zona merah agar dapat memutus persebaran virus COVID-19. Selain itu, karena besarnya dampak di bidang perekonomian akibat PSBB, pemerintah mengeluarkan kebijakan new normal dengan memperhatikan protokol kesehatan terkait COVID-19 [4]. Menteri Kesehatan RI juga telah mengeluarkan aturan mengenai protokol kesehatan bagi masyarakat untuk mengurangi risiko penularan COVID-19. Aturan tersebut diantaranya menjaga jarak fisik, memakai masker setiap hendak keluar rumah, istirahat yang cukup, serta selalu menerapkan perilaku hidup sehat dan bersih, seperti memakan makanan bergizi [5]. Implementasi protokol kesehatan tersebut tidak akan maksimal apabila tidak didukung dengan partisipasi masyarakat. Pada Februari 2021, berdasarkan hasil survei yang dilaksanakan oleh [6], sebanyak 71 kota dan kabupaten memiliki tingkat kepatuhan memakai masker $<60 \%$ selama seminggu terakhir. Artinya, masih terdapat segelintir masyarakat yang abai terhadap protokol kesehatan. Namun, sebagian besar masyarakat, sebanyak 121 kota dan kabupaten, memiliki tingkat kepatuhan memakai masker sekitar 91 $100 \%$.

Perilaku yang dilakukan masyarakat terkait penerapan protokol kesehatan cenderung diawali atau didasari dengan adanya persepsi terhadap perilaku tersebut. Hasil penelitian yang dilakukan oleh [7] mengenai HBM (Health Belief Model) menyatakan bahwa dengan ditentukannya persepsi oleh seseorang terhadap penyakitnya serta kecenderungannya untuk bertindak dapat memprediksi jika seseorang tersebut melaksanakan perilaku kesehatan yang positif. Komponen dari HBM tersebut antara lain perceived suspectibility, perceived benefits, perceived barriers, dan cues to action. Pertama, perceived suspectibility mengacu pada keyakinan tentang kemungkinan seseorang terjangkit penyakit atau mengalami kondisi tertentu. Ketika seseorang memiliki kepercayaan bahwa mereka rentan terjangkit suatu penyakit, mereka cenderung lebih sering melakukan tindakan pencegahan terhadap penyakitnya tersebut. Kedua, perceived benefits adalah keyakinan bahwa seseorang akan mendapat suatu manfaat jika melakukan tindakan pencegahan saat dirinya merasa rentan terhadap suatu penyakit tertentu. Ketiga, perceived barriers merupakan keyakinan seseorang mengenai gangguan atau alangan yang dihadapi dalam melakukan tindakan kesehatan atau tindakan pencegahan terhadap suatu penyakit. Apabila gangguan yang dihadapinya kecil, maka peluang orang tersebut untuk melaksanakan tindakan pencegahan akan semakin besar. Keempat, cues to action merupakan isyarat yang pemicunya adalah pengaruh dari media social, media massa, dan orang terdekat yang membuat seseorang bergerak ke arah perilaku pencegahan [8]. Selain itu, selama pandemi, tingkat keparahan COVID-19 yang dirasa tinggi (perceived severity) membuat masyarakat enggan terlibat dengan dunia luar. Perceived severity merujuk pada keyakinan seseorang jika dirinya terjangkit suatu penyakit, dirinya akan mengalami kondisi yang parah [9]. Adanya kepercayaan terhadap kebijakan pemerintah merupakan salah satu faktor yang dapat meningkatkan sikap positif masyarakat dalam mematuhi peraturan penanganan dan pencegahan COVID-19 [10]. Selain itu, berdasarkan penelitian yang dilakukan 
oleh [11], pengetahuan terhadap COVID-19 merupakan salah satu faktor yang berpengaruh terhadap kepatuhan masyarakat terhadap protokol kesehatan.

Berdasarkan uraian di atas, alasan yang mendasari penelitian ini adalah perkembangan kasus positif dan penularan COVID-19 masih tinggi, tetapi tidak semua masyarakat memiliki kesadaran untuk menerapkan protokol kesehatan. Oleh karena itu, peneliti tertarik untuk menganalisis faktor yang memengaruhi kepatuhan masyarakat terhadap protokol kesehatan menggunakan metode analisis faktor (factor analysis). Berdasarkan hal tersebut, penelitian ini bertujuan untuk mengidentifikasi faktor yang dapat memengaruhi kepatuhan masyarakat terhadap protokol kesehatan. Penelitian ini diharapkan dapat memberikan wawasan mengenai faktor secara umum yang memengaruhi kepatuhan masyarakat terhadap protokol kesehatan dan menjadi acuan dalam melakukan penertiban masyarakat yang mengabaikannya.

\section{METODE PENELITIAN}

Penelitian ini merupakan penelitian dengan metode kuantitatif. Metode kuantitatif adalah metode yang berlandaskan filsafat positivisme untuk meneliti populasi tertentu dengan data berupa angka dengan menggunakan analisis statistik [12]. Data yang digunakan pada penelitian ini merupakan data primer mengenai faktor-faktor yang memengaruhi tingkat kepatuhan masyarakat terhadap protokol kesehatan. Sumber data primer didefinisikan sebagai data yang didapatkan langsung oleh pengumpul data dari pihak pertama [13]. Data ini dikatakan data primer karena didapatkan penulis melalui survei menggunakan bantuan Google Form dan disebarkan secara online melalui media sosial. Pada survei tersebut, terdapat 100 responden dengan usia diantara 17 - 63 tahun yang melakukan pengisian. Metode penelitian yang digunakan adalah analisis faktor dengan melibatkan delapan variabel yang diduga sebagai faktor-faktor yang memengaruhi tingkat kepatuhan masyarakat terhadap protokol kesehatan.

\subsection{Variabel Penelitian}

Pada penelitian ini, variabel yang digunakan adalah sesuai dengan yang telah dipaparkan pada Tabel 1, sebagai berikut:

Tabel 1. Uraian Variabel Penelitian

\begin{tabular}{|c|c|c|}
\hline Variabel & Pernyataan & Indikator \\
\hline $\begin{array}{l}\text { Pengetahuan } \\
\text { tentang COVID- } \\
19\left(\boldsymbol{X}_{\mathbf{1}}\right)\end{array}$ & $\begin{array}{c}\text { Anda mematuhi protokol kesehatan karena Anda memiliki } \\
\text { pengetahuan tentang COVID-19 dan bahayanya. }\end{array}$ & \multirow{8}{*}{$\begin{array}{l}1=\text { Sangat Tidak } \\
\text { Sesuai } \\
2=\text { Tidak Sesuai } \\
3=\text { Cukup Sesuai } \\
4=\text { Sesuai } \\
5=\text { Sangat Sesuai }\end{array}$} \\
\hline $\begin{array}{l}\text { Kepercayaan } \\
\text { terhadap } \\
\text { Pemerintah }\left(\boldsymbol{X}_{\mathbf{2}}\right)\end{array}$ & $\begin{array}{l}\text { Anda mematuhi protokol kesehatan karena Anda percaya } \\
\text { terhadap kebijakan pemerintah terkait penanganan COVID-19. }\end{array}$ & \\
\hline $\begin{array}{l}\text { Perceived } \\
\text { Susceptibility } \\
\left(\boldsymbol{X}_{\mathbf{3}}\right)\end{array}$ & $\begin{array}{l}\text { Anda mematuhi protokol kesehatan karena Anda meyakini } \\
\text { adanya kerentanan diri terhadap risiko terjangkit COVID-19. }\end{array}$ & \\
\hline $\begin{array}{l}\text { Perceived } \\
\text { Severity }\left(\boldsymbol{X}_{\mathbf{4}}\right)\end{array}$ & $\begin{array}{l}\text { Anda mematuhi protokol kesehatan karena Anda meyakini bahwa } \\
\text { COVID-19 akan menimbulkan efek yang parah terhadap } \\
\text { penderitanya. }\end{array}$ & \\
\hline $\begin{array}{c}\text { Perceived } \\
\text { Benefits }\left(\boldsymbol{X}_{\mathbf{5}}\right)\end{array}$ & $\begin{array}{l}\text { Anda mematuhi protokol kesehatan karena Anda meyakini bahwa } \\
\text { Anda akan mendapatkan manfaat dari hal tersebut }\end{array}$ & \\
\hline $\begin{array}{c}\text { Perceived } \\
\text { Barriers }\left(\boldsymbol{X}_{\mathbf{6}}\right)\end{array}$ & $\begin{array}{l}\text { Anda mematuhi protokol kesehatan karena tidak adanya } \\
\text { hambatan dalam pelaksanaannya. }\end{array}$ & \\
\hline $\begin{array}{l}\text { Cues to Action } \\
\qquad\left(\boldsymbol{X}_{7}\right)\end{array}$ & $\begin{array}{c}\text { Anda mematuhi protokol kesehatan karena adanya pengaruh atau } \\
\text { dorongan dari orang lain, misalnya nasihat, iklan layanan } \\
\text { masyarakat, dan lain-lain. }\end{array}$ & \\
\hline $\begin{array}{c}\text { Kejelasan } \\
\text { Informasi }\left(\boldsymbol{X}_{\mathbf{8}}\right)\end{array}$ & $\begin{array}{c}\text { Anda mematuhi protokol kesehatan karena informasi dan } \\
\text { himbauan yang Anda dapat mengenainya sudah tersampaikan } \\
\text { dengan jelas. }\end{array}$ & \\
\hline
\end{tabular}




\subsection{Uji Validitas dan Reliabilitas Instrumen Penelitian}

Sebelum melakukan analisis faktor, data yang didapat dari hasil survei harus diuji validitas dan reliabilitas. Hal ini dikarenakan suatu instrumen penelitian dikatakan baik jika dikatakan valid dan reliabel. Suatu instrumen dikatakan valid jika jika dapat mengungkap data dari suatu variabel sesuai dengan keadaan sebenarnya. Instrumen dikatakan reliabel saat dapat mengungkap data yang dapat dipercaya. Oleh karena itu, perlu dilakukan uji validitas dan reliabilitas untuk mengetahuinya. Uji validitas merupakan uji yang dilakukan untuk mengetahui ketepatan pengukuran untuk mengukur sesuatu. Sementara itu, reliabilitas berkaitan dengan konsistensi dari suatu alat ukur [14].

\subsection{Analisis Faktor}

Analisis faktor adalah analisis statistik yang digunakan untuk mereduksi beberapa variabel independen menjadi lebih sedikit [15]. Analisis faktor dilakukan untuk menjelaskan struktur hubungan antarvariabel dalam bentuk faktor. Faktor yang terbentuk merupakan besaran acak (random quantities) yang sebelumnya tidak dapat ditentukan secara langsung [16]. Untuk melakukan analisis faktor, langkah-langkah yang perlu dilakukan adalah sebagai berikut [17]:

a. Perumusan Masalah

Langkah awal dalam melakukan analisis faktor adalah perumusan masalah. Hal ini bertujuan untuk menentukan arah penelitian.

b. Uji Asumsi

Uji asumsi dilakukan untuk mengetahui apakah variabel yang telah ditentukan dapat digunakan untuk analisis faktor. Pengujian asumsi ini didasarkan atas korelasi antarvariabel dan kelayakan variabel. Korelasi antarvariabel dapat dilihat pada matriks korelasi. Apabila korelasi antarvariabel besar, analisis faktor tepat untuk digunakan, begitu pula sebaliknya. Kelayakan variabel dapat ditentukan berdasarkan KMO (Kayser-Meyers-Oklin) dan MSA (Measure of Sampling Adequacy). Apabila nilai KMO dan MSA kurang dari 0,5 , variabel belum sesuai untuk digunakan dalam analisis faktor sehingga perlu dilakukan pengulangan uji asumsi dengan tidak memasukkan variabel dengan MSA kurang dari 0,5 dalam perhitungan. Apabila ada lebih dari satu variabel yang memiliki MSA kurang dari 0,5, variabel yang dikeluarkan adalah variabel dengan MSA terkecil.

c. Penentuan Banyak Faktor

Terdapat beberapa prosedur untuk menentukan banyak faktor, diantaranya:

1. A priori determination

A priori determination merupakan cara untuk menentukan banyak faktor berdasarkan penelitian sebelumnya.

2. Determination based on eigen values

Determination based on eigen values merupakan penentuan banyak faktor berdasarkan eigen values yang nilainya lebih dari 1.

3. Determination based on scree plot

Determination based on scree plot merupakan penentuan banyak faktor berdasarkan plot eigen values atau scree plot.

4. Determination based on percentage of variance

Determination based on percentage of variance merupakan penentuan banyak faktor berdasarkan persentase varians yang dijelaskan beberapa faktor.

5. Determination based on split-half reliability

Determination based on split-half reliability merupakan penentuan banyak faktor dengan membagi sampel menjadi dua bagian.

d. Pemfaktoran dan Rotasi Faktor

Pemfaktoran (factoring) merupakan langkah untuk mendapatkan sala satu atau lebih faktor-faktor untuk menggantikan variabel asal. Untuk melakukan pemfaktoran, metode yang dapat digunakan adalah Principal Component Analysis (PCA) dan Common Factor Analysis (analisis common factor). Pada proses pemfaktoran, salah satu hasil dari analisis faktor adalah matriks faktor, yang disebut juga factor pattern matrix (matriks pola faktor). Di dalam suatu matriks yang kompleks, interpretasi faktor menjadi sulit dilakukan sehingga rotasi faktor perlu dilakukan untuk lebih memperjelas variabel-variabel asal yang dikategorikan dalam faktor tertentu. Melalui rotasi faktor, faktor diubah ke dalam bentuk yang lebih sederhana agar lebih mudah untuk diinterpretasikan, dengan harapan setiap faktor memiliki nilai 
signifikan. Rotasi tidak berpengaruh pada communalities dan persentase varians total yang dijelaskan. Varians yang dijelaskan oleh faktor individual didistribusikan ulang melalui proses rotasi. Untuk melakukan rotasi, terdapat beberapa jenis metode. Penggunaan metode rotasi yang berbeda akan menghasilkan identifikasi faktor yang berbeda. Metode rotasi yang digunakan pada penelitian ini adalah varimax. Metode varimax bertujuan untuk meminimalisasi banyak variabel dengan nilai loading yang tinggi pada faktor sehingga kemampuan interpretasi faktor faktor yang ada semakin meningkat.

e. Interpretasi Faktor

Interpretasi faktor dilakukan dengan melakukan pengelompokan variabel asal berdasarkan nilai loading yang lebih besar dalam satu faktor. Setelah pengelompokkan, faktor-faktor yang terbentuk perlu diberi label yang mencerminkan variabel-variabel asal yang membentuknya.

\section{HASIL DAN PEMBAHASAN}

Dari data yang telah diperoleh, selanjutnya, dilakukan proses analisis data. Bagian hasil dan pembahasan memberikan penjelasan mengenai Uji Validitas dan Reliabilitas Instrumen Penelitian dan Analisis Faktor.

\subsection{Uji Validitas dan Reliabilitas Instrumen Penelitian}

Untuk uji validitas, berdasarkan nilai Pearson Correlation (r) dengan banyak data (n) sebanyak 100, didapatkan derajat bebas (df) sebesar 98 sehingga nilai $\mathrm{r}$ tabel dengan alpha 0,05 dan derajat bebas 98 adalah 0,1966 .

a. Jika $r$ hitung $>r$ tabel atau $r$ hitung $>0,1966$, butir pertanyaan dari kuesioner valid

b. Jika $r$ hitung $<\mathrm{r}$ tabel atau $\mathrm{r}$ hitung $<0,1966$, butir pertanyaan dari kuesioner tidak valid

Tabel 2. Hasil Pengujian Validitas

\begin{tabular}{cccc}
\hline $\begin{array}{c}\text { Indikator } \\
\text { Variabel }\end{array}$ & $\mathbf{r}$ hitung & $\mathbf{r}$ tabel & Keterangan \\
\hline $\boldsymbol{X}_{\mathbf{1}}$ & 0,583 & 0,1966 & Valid \\
\hline $\boldsymbol{X}_{\mathbf{2}}$ & 0,657 & 0,1966 & Valid \\
\hline $\boldsymbol{X}_{\mathbf{3}}$ & 0,672 & 0,1966 & Valid \\
\hline $\boldsymbol{X}_{\mathbf{4}}$ & 0,651 & 0,1966 & Valid \\
\hline $\boldsymbol{X}_{\mathbf{5}}$ & 0,757 & 0,1966 & Valid \\
\hline $\boldsymbol{X}_{\mathbf{6}}$ & 0,585 & 0,1966 & Valid \\
\hline $\boldsymbol{X}_{\mathbf{7}}$ & 0,565 & 0,1966 & Valid \\
\hline $\boldsymbol{X}_{\mathbf{8}}$ & 0,609 & 0,1966 & Valid \\
\hline
\end{tabular}

Pada Tabel 2, terlihat bahwa korelasi masing-masing skor dari indikator variabel dengan total skor menunjukkan hasil yang signifikan. Hal ini ditunjukkan oleh keseluruhan indikator variabel penelitian mempunyai $r$ hitung $>r$ tabel atau $r$ hitung $>0,1966$ sehingga dapat disimpulkan bahwa keseluruhan indikator variabel penelitian valid untuk digunakan sebagai instrumen dalam penelitian atau pernyataan yang digunakan untuk mengukur variabel yang diteliti.

Tabel 3. Hasil Pengujian Reliabilitas

\begin{tabular}{cccc}
\hline $\begin{array}{c}\text { Cronbach's } \\
\text { Alpha }\end{array}$ & N of Items & r tabel & Keterangan \\
\hline 0,783 & 8 & 0,1966 & Reliabel \\
\hline
\end{tabular}

Hasil Uji Reliabilitas pada Tabel 3 tersebut menunjukkan bahwa nilai Cronbach's Alpha sebesar 0,783 melebihi nilai $r$ tabel. Dengan demikian, indikator untuk setiap variabel pada kuesioner memiliki tingkat reliabilitas yang baik.

\subsection{Analisis Faktor}

Analisis faktor merupakan suatu metode yang digunakan untuk menemukan suatu cara meringkas informasi yang ada pada variabel asli menjadi satu kelompok variabel baru yang disebut faktor. 


\subsubsection{Bartlett's Test of Sphericity dan KMO}

Uji KMO dilakukan untuk mengetahui kelayakan variabel yang digunakan. Seluruh variabel dikatakan valid apabila nilai KMO dan Bartlett's Test lebih dari 0,5.

Tabel 4. Hasil Uji Bartlett's Test of Sphericity dan KMO

\begin{tabular}{cc}
\hline Kaiser-Meyer-Olkin Measure of Sampling Adequacy & 0,762 \\
\hline Sig. & 0,000 \\
\hline
\end{tabular}

Seperti yang tertera pada Tabel 4, nilai KMO and Bartlett's Test adalah sebesar 0,762 dengan signifikansi 0,000 . Oleh karena nilai tersebut sudah lebih dari 0,5 dan signifikansi kurang dari 0,05 (alpha $=$ $5 \%$ ), variabel dan sampel telah layak sehingga dapat dianalisis lebih lanjut.

\subsubsection{Anti Image}

Anti Image berguna untuk melihat variabel-variabel yang layak untuk analisis faktor dan mengetahui kekuatan korelasi variabel-variabel tersebut faktor-faktor yang dijadikan sebagai faktor analisis mempunyai. Kriteria pengujiannya adalah variabel dikatakan layak apabila nilai MSA (Measure of Sampling Adequacy) lebih besar atau sama dengan 0,5 [18].

Tabel 5. Hasil Anti Image

\begin{tabular}{cc}
\hline Variabel & MSA \\
\hline $\boldsymbol{X}_{\mathbf{1}}$ & 0,748 \\
\hline $\boldsymbol{X}_{\mathbf{2}}$ & 0,780 \\
\hline $\boldsymbol{X}_{\mathbf{3}}$ & 0,844 \\
\hline $\boldsymbol{X}_{\mathbf{4}}$ & 0,789 \\
\hline $\boldsymbol{X}_{\mathbf{5}}$ & 0,742 \\
\hline $\boldsymbol{X}_{\mathbf{6}}$ & 0,726 \\
\hline $\boldsymbol{X}_{\mathbf{7}}$ & 0,725 \\
\hline $\boldsymbol{X}_{\mathbf{8}}$ & 0,724 \\
\hline
\end{tabular}

Berdasarkan Tabel 5 di atas, dapat diketahui bahwa seluruh variabel memiliki nilai MSA yang lebih besar dari 0,5 sehingga seluruh variabel layak digunakan untuk analisis faktor.

\subsubsection{Communalities}

Communalities adalah jumlah varians dari suatu variabel mula-mula yang dapat dijelaskan oleh faktor yang ada. Semakin besar nilai communalities sebuah variabel, semakin erat hubungan dengan faktor yang terbentuk [19].

Tabel 6. Communalities

\begin{tabular}{cc}
\hline Variabel & Communalities \\
\hline $\boldsymbol{X}_{\mathbf{1}}$ & 0,724 \\
\hline $\boldsymbol{X}_{\mathbf{2}}$ & 0,633 \\
\hline $\boldsymbol{X}_{\mathbf{3}}$ & 0,458 \\
\hline $\boldsymbol{X}_{\mathbf{4}}$ & 0,512 \\
\hline $\boldsymbol{X}_{\mathbf{5}}$ & 0,650 \\
\hline $\boldsymbol{X}_{\mathbf{6}}$ & 0,303 \\
\hline $\boldsymbol{X}_{\mathbf{7}}$ & 0,616 \\
\hline $\boldsymbol{X}_{\mathbf{8}}$ & 0,566 \\
\hline
\end{tabular}

Berdasarkan Tabel 6 di atas, dapat diketahui bahwa variabel Pengetahuan tentang COVID-19 $\left(X_{1}\right)$ memiliki nilai communalities sebesar 0,724 . Artinya, $72,4 \%$ varians dari variabel $X_{1}$ dapat dijelaskan oleh faktor yang tebentuk. Nilai communalities variabel Kepercayaan Terhadap Pemerintah $\left(X_{2}\right)$ sebesar 63,3\%. Artinya, $63,3 \%$ varians dari variabel $X_{2}$ dapat dijelaskan oleh faktor yang tebentuk. Nilai communalities variabel Perceived Sucseptibility $\left(X_{3}\right)$ sebesar 45,8\%. Artinya, 45,8\% varians dari variabel $X_{3}$ dapat dijelaskan oleh faktor yang tebentuk. Selanjutnya, variabel Perceived Severity $\left(X_{4}\right)$ memiliki nilai communalities sebesar 51,2\%. Artinya, 51,2\% varians dari variabel $X_{4}$ dapat dijelaskan oleh faktor yang 
terbentuk. Variabel Perceived Benefit $\left(X_{5}\right)$ memiliki nilai communalities sebesar $65 \%$. Artinya, $65 \%$ varians dari variabel $X_{5}$ dapat dijelaskan oleh faktor yang terbentuk. Nilai communalities variabel Perceived Barrier $\left(X_{6}\right)$ sebesar $30,3 \%$. Artinya, 30,3\% varians dari variabel $X_{6}$ dapat dijelaskan oleh faktor yang tebentuk. Nilai communalities variabel Cues to Action $\left(X_{7}\right)$ sebesar $61,6 \%$. Artinya, $61,6 \%$ varians dari variabel $X_{7}$ dapat dijelaskan oleh faktor yang terbentuk. Nilai communalities variabel Kejelasan Informasi $\left(X_{8}\right)$ sebesar $56,6 \%$. Artinya, 56,6\% varians dari variabel $X_{8}$ dapat dijelaskan oleh faktor yang terbentuk. Berdasarkan hasil tersebut, dapat disimpulkan bahwa variabel Pengetahuan Tentang Covid-19 $\left(X_{1}\right)$ memiliki hubungan yang paling erat dengan faktor yang terbentuk.

\subsubsection{Total Variance Explained}

Langkah selanjutnya adalah menentukan faktor yang terbentuk. Kriteria pengujiannya adalah nilai eigen harus lebih dari 1.

Tabel 7. Total Variance Explained

\begin{tabular}{cccc}
\hline & \multicolumn{4}{c}{ Extraction Sums of Squared Loadings } \\
\hline Variabel & Total & $\begin{array}{c}\text { Loadings (\%) of } \\
\text { Variance }\end{array}$ & Cumulative (\%) \\
& & 41.914 & 41.914 \\
\hline Factor 1 & 3.353 & 13.875 & 55.789 \\
\hline Factor 2 & 1.110 & & \\
\hline
\end{tabular}

Berdasarkan Tabel 7, dapat diketahui bahwa terdapat 2 faktor yang dapat dibentuk dengan eigen value di atas 1. Jika kedelapan variabel tersebut diringkas menjadi satu faktor, varians yang dapat dijelaskan oleh satu faktor tersebut adalah sebesar $3,353 / 8 \times 100 \%=41,914 \%$. Sementara itu, jika 8 variabel tersebut diekstrak menjadi 2 faktor, varians faktor pertama adalah $41,914 \%$ dan varians faktor kedua adalah 1,110/8 x $100 \%=13,875 \%$ sehingga dua faktor tersebut dapat menjelaskan variabilitas kedelapan variabel sebesar $41,914 \%+13,875 \%=55,789 \%$.

\subsubsection{Scree Plot}

Penentuan banyak faktor juga dapat dilakukan berdasarkan scree plot.

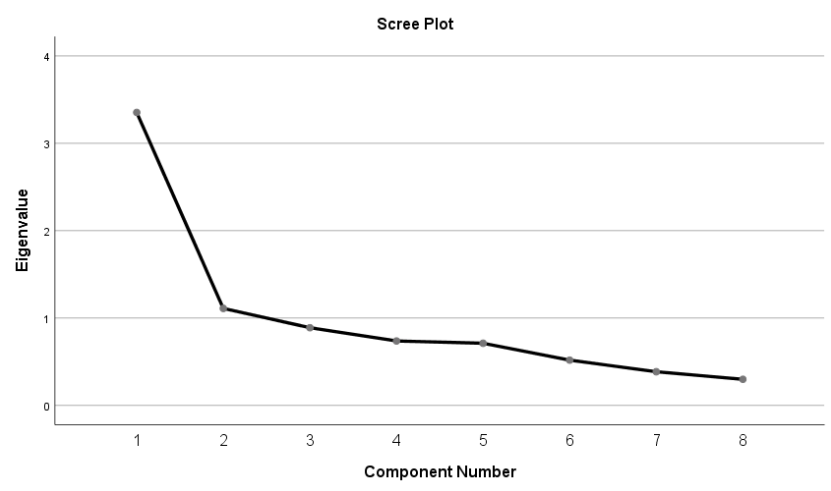

Gambar 1. Scree Plot

Pada Gambar 1, terlihat bahwa terjadi penurunan eigen values secara drastis dari faktor 1 ke faktor 2 . Pada faktor-faktor selanjutnya, eigen values mengalami perubahan nilai yang tidak drastis. Selain itu, dapat dilihat pula bahwa eigen values pada faktor 3 sudah menunjukkan angka kurang dari 1. Dengan demikian, penggunaan dua faktor merupakan langkah yang paling optimal untuk meringkas kedelapan variabel tersebut.

\subsubsection{Component Matrix}

Component matrix digunakan untuk mengelompokkan variabel berdasarkan kontribusi pada tiap komponen (faktor). Variabel yang memiliki kontribusi terbesar pada komponen tertentu akan dikelompokkan pada komponen (faktor) tersebut. 
Tabel 8. Component Matrix

\begin{tabular}{ccc}
\hline \multirow{2}{*}{ Variabel } & \multicolumn{2}{c}{ Component } \\
\cline { 2 - 3 } & $\mathbf{1}$ & $\mathbf{2}$ \\
\hline $\boldsymbol{X}_{\mathbf{1}}$ & 0,646 & $-0,554$ \\
\hline $\boldsymbol{X}_{\mathbf{2}}$ & 0,685 & $-0,405$ \\
\hline $\boldsymbol{X}_{\mathbf{3}}$ & 0,677 & $-0,004$ \\
\hline $\boldsymbol{X}_{\mathbf{4}}$ & 0,700 & $-0,148$ \\
\hline $\boldsymbol{X}_{\mathbf{5}}$ & 0,795 & 0,134 \\
\hline $\boldsymbol{X}_{\mathbf{6}}$ & 0,535 & 0,131 \\
\hline $\boldsymbol{X}_{\mathbf{7}}$ & 0,474 & 0,626 \\
\hline $\boldsymbol{X}_{\mathbf{8}}$ & 0,613 & 0,436
\end{tabular}

Pada Tabel 8, terlihat bahwa terdapat variabel yang memiliki nilai korelasi yang sama besar untuk beberapa faktor sehingga untuk memperjelas pengelompokkan suatu variabel, perlu dilakukan rotasi.

\subsubsection{Rotated Component Matrix}

Sesuai penjelasan pada pembahasan 3.1, perlu dilakukan rotasi untuk memperjelas pengelompokkan suatu variabel ke dalam faktor (komponen). Dalam hal ini, rotasi dilakukan menggunakan metode VARIMAX. Variabel yang memiliki kontribusi terbesar pada komponen tertentu akan dikelompokkan pada komponen (faktor) tersebut.

Tabel 9. Rotated Component Matrix

\begin{tabular}{ccc}
\hline \multirow{2}{*}{ Variabel } & \multicolumn{2}{c}{ Component } \\
\cline { 2 - 3 } & $\mathbf{1}$ & $\mathbf{2}$ \\
\hline $\boldsymbol{X}_{\mathbf{1}}$ & 0,851 & $-0,003$ \\
\hline $\boldsymbol{X}_{\mathbf{2}}$ & 0,784 & 0,136 \\
\hline $\boldsymbol{X}_{\mathbf{3}}$ & 0,518 & 0,436 \\
\hline $\boldsymbol{X}_{\mathbf{4}}$ & 0,629 & 0,342 \\
\hline $\boldsymbol{X}_{\mathbf{5}}$ & 0,518 & 0,618 \\
\hline $\boldsymbol{X}_{\mathbf{6}}$ & 0,322 & 0,447 \\
\hline $\boldsymbol{X}_{\mathbf{7}}$ & $-0,046$ & 0,784 \\
\hline $\boldsymbol{X}_{\mathbf{8}}$ & 0,184 & 0,730 \\
\hline
\end{tabular}

Pada Tabel 9, dapat dilihat bahwa variabel yang masuk ke dalam komponen (faktor) 1 adalah variabel Pengetahuan tentang COVID-19 $\left(X_{1}\right)$, Kepercayaan Terhadap Pemerintah $\left(X_{2}\right)$, Perceived Sucseptibility $\left(X_{3}\right)$, dan Perceived Severity $\left(X_{4}\right)$. Faktor 1 ini diberi nama faktor Persepsi Tentang COVID-19. Sementara itu, variabel yang termasuk dalam komponen (faktor) 2 adalah Perceived Benefit $\left(X_{5}\right)$, Perceived Barrier $\left(X_{6}\right)$, Cues to Action $\left(X_{7}\right)$, dan Kejelasan Informasi $\left(X_{8}\right)$. Faktor 2 ini diberi nama faktor Persepsi Tentang Protokol Kesehatan

\section{KESIMPULAN}

Pada penelitian ini, terdapat delapan variabel yang dianalisis dan terbukti bahwa seluruh variabel layak untuk dianalisis menggunakan metode analisis faktor. Setelah dilakukan analisis faktor, didapatkan hasil bahwa delapan variabel tersebut dapat direduksi menjadi dua faktor yang masing-masing faktor diberi nama faktor Persepsi Tentang COVID-19 dan faktor Persepsi Tentang Protokol Kesehatan. Dari hasil tersebut, dapat disimpulkan bahwa persepsi memiliki peranan besar dalam perubahan perilaku kesehatan, termasuk kepatuhan terhadap protokol kesehatan. Oleh karena itu, untuk mengubah persepsi masyarakat diperlukan suatu upaya. Salah satunya adalah peningkatan kuantitas serta kualitas penyebaran informasi mengenai pentingnya penerapan protokol kesehatan secara langsung ataupun melalui media sosial. Hal ini ditujukan agar dapat mengurangi penyebaran COVID-19.

\section{DAFTAR PUSTAKA}

[1] D. Handayani, D. R. Hadi, F. Isbaniah, E. Burhan, and H. Agustin, "Penyakit Virus Corona 2019", J. Respir. Indo., vol. 40, 
no. 2, pp. 119-129, April 2020.

[2] Kementerian Sekretariat Negara Republik Indonesia, Keputusan Presiden Republik Indonesia Nomor 11 Tahun 2020 Tentang Penetapan Kedaruratan Kesehatan Masyarakat Corona Virus Disease 2019 (COVID-19), Jakarta : Kementerian Sekretariat Negara Republik Indonesia, 2020.

[3] A. Wibowo, "Empat Strategi Pemerintah Atasi COVID-19", Satuan Tugas Penanganan COVID-19, 8 April 2020, [Online]. Available: https://covid19.go.id/p/berita/empat-strategi-pemerintah-atasi-covid-19. [Accessed: 17 June 2021].

[4] Kementerian Dalam Negeri Republik Indonesia, Pedoman Manajemen Bagi Pemerintah Daerah Dalam Penanganan COVID-19 dan Dampaknya, Jakarta : Kementerian Dalam Negeri Republik Indonesia, 2020.

[5] Kementerian Kesehatan Republik Indonesia, Keputusan Menteri Kesehatan Republik Indonesia Nomor HK.01.07/MenKes/413/2020 Tentang Pedoman Pencegahan dan Pengendalian Corona Virus Disease 2019 (Covid-19), Jakarta : Kementerian Kesehatan Republik Indonesia, 2020.

[6] Satuan Tugas Penanganan COVID-19, Monitoring Kepatuhan Protokol Kesehatan Tingkat Nasional, Jakarta : Satuan Tugas Penanganan COVID-19, 2021.

[7] M. H. Becker, "The Health Belief Model and Sick Role Behaviour", Health Education Monogr., vol. 2, no. 4, pp. 409-419, 1974.

[8] A. P. Pramono, “Analisis Faktor Kepatuhan Pemenuhan Kebutuhan Gizi Pada Klien Dengan Diabetes Mellitus Berbasis Teori Health Belief Model”, S. Kep, [Thesis], Nurs. Faculty, Airlangga Univ., Surabaya, 2019, [online]. Available : http://repository.unair.ac.id/85150/.

[9] J. Qiu, B. Shen, M. Zhao, Z. Wang, B. Xie, and Y. Xu, “A nationwide survey of psychological distress among Chinese people in the COVID-19 epidemic: Implications and policy recommendations," Gen. Psychiatry, vol. 33, no. 2, pp. 19-21, 2020.

[10] R.K. Webster, S. K. Brooks, L.E. Smith, L.Woodland, S. Wessely, and G. J. Rubin, "How To Improve Adherence with Quarantine : Rapid Review of The Evidence", Public Health, vol. 182, pp. 163-169, 2020.

[11] N. Afrianti and C. Rahmiati, "Faktor-Faktor Yang Mempengaruhi Kepatuhan Masyarakat Terhadap Protokol Kesehatan Covid-19," J. Ilm. Permas, vol. 11, no. 1, pp. 113-124, 2021.

[12] Sugiyono, Metode Penelitian Pendidikan, Bandung: Alfabeta, 2015.

[13] V. Herviani and A. Febriansyah, "Tinjauan Atas Proses Penyusunan Laporan Keuangan Pada Young Enterpreneur Academy Indonesia Bandung”, J. Ris. Akunt., vol. 8, no. 2, pp. 19-27, October 2016.

[14] F. Yusup, “Uji Validitas dan Reliabilitas Instrumen Penelitian Kuantitatif”, J. Tarb., vol. 7, no. 1, pp. 17-23, 2018.

[15] A. Baroroh, Analisis Multivariat dan Time Series dengan SPSS 21, Jakarta: PT Elex Media Komputindo, 2013.

[16] R. Firdaos, “Aplikasi Analisis Faktor Konfirmatori Terhadap Sikap Keberagamaan Mahasiswa”, J. INFERENSI, vol. 10, no. 2 , pp. 359-380, 2016.

[17] F. Elpira, "Penerapan Analisis Faktor untuk Menentukan Faktor-faktor yang Mempengaruhi Mahasiswa dalam Memilih Jurusan Matematika Fakultas Sains dan Teknologi Universitas Islam Negeri Alauddin Makassar", S.Si, [Thesis], Sci. and Tech. Faculty, Alauddin Islamic Univ., Makassar, 2014, [online]. Available: http://repositori.uin-alauddin.ac.id/7380/.

[18] I. Ghozali, "Aplikasi Analisis Multivariat Dengan Program SPSS", Semarang: Badan Penerbit Universitas Diponegoro, 2011.

[19] S. Santoso, Statistik Multivariat, Konsep dan Aplikasi dengan SPSS, Bandung: PT Elex Media Komputindo, 2011. 
